\begin{abstract}
Iranica
Abstracta Iranica Revue bibliographique pour le domaine irano-aryen

Volume 40-41 | 2019

Comptes rendus des publications de 2017-2018
\end{abstract}

\title{
Johannes Hackl. „Zur Sprachsituation im Babylonien des ersten Jahrtausends v.Chr.“
}

\section{Astrid Nunn}

\section{(2) OpenEdition}

1 Journals

\section{Édition électronique}

URL : http://journals.openedition.org/abstractairanica/49421

DOI : 10.4000/abstractairanica.49421

ISBN : 1961-960X

ISSN : 1961-960X

Éditeur :

CNRS (UMR 7528 Mondes iraniens et indiens), Éditions de l'IFRI

Référence électronique

Astrid Nunn, « Johannes Hackl. „Zur Sprachsituation im Babylonien des ersten Jahrtausends v.Chr." », Abstracta Iranica [En ligne], Volume 40-41 | 2019, document 56, mis en ligne le 30 octobre 2019, consulté le 24 avril 2021. URL : http://journals.openedition.org/abstractairanica/49421 ; DOI : https:// doi.org/10.4000/abstractairanica.49421

Ce document a été généré automatiquement le 24 avril 2021.

Tous droits réservés 


\title{
Johannes Hackl. „Zur Sprachsituation im Babylonien des ersten Jahrtausends v.Chr."
}

\author{
Astrid Nunn
}

\section{RÉFÉRENCE}

Johannes Hackl. „Zur Sprachsituation im Babylonien des ersten Jahrtausends v.Chr.“ in Sebastian Fink, Martin Lang, Manfred Schretter (eds.). Mehrsprachigkeit. Vom Alten Orient bis zum Esperanto. Münster : Zaphon, 2018, p. 209-238 (dubsar 2)

1 Une seule contribution concerne l'époque achéménide dans ce volume dédié au bilinguisme et au multilinguisme de l'antiquité sumérienne au latin et à l'espéranto de l'époque moderne. L'A. essaie de définir les caractéristiques de l'accadien néobabylonien et du babylonien tardif (Neu- und spätbabylonisch) qui englobe l'époque achéménide, entre autres en analysant l'ordre des mots. Il conclue que l'accadien ne change pratiquement plus entre la fin du VIIème s. et les deux derniers siècles av. J.-C. La différentiation entre néo-babylonien et babylonien tardif devient obsolète. La fin du VIIème siècle n'est pas due au hasard. Les décennies autour de 600 av. J.-C. correspondent à des contacts intenses entre populations akkadisante et araméenne. 


\section{AUTEURS}

\section{ASTRID NUNN}

Université de Munich 